\title{
Eating Patterns and Adherence to the Mediterranean Diet: A Cross-Sectional Study in Albania
}

\author{
Kristela Jaupaj, \\ Brunilda Subashi, \\ Research Center of Public Health, Faculty of Public Health, Albania \\ Inva Zotaj, \\ University of Vlore “' Ismail Qemali”, Vlore, Albania \\ Jerina Jaho, \\ Fatjona Kamberi, \\ Research Center of Public Health, Faculty of Public Health, Albania
}

Doi:10.19044/esj.2020.v16n21p11 ＵRL:http://dx.doi.org/10.19044/esj.2020.v16n21p11

\begin{abstract}
Objective: To evaluate the level of adherence to the Mediterranean diet pattern overall and to specific dietary components, among Albanian adults. Design and Setting: This is a cross-sectional study carried out during June - July 2019 in Vlora and Fieri cities, Albania. The study population consisted of 209 adults, randomly selected. Participation rate was 73\%. Adherence to the Mediterranean diet was assessed via an online questionnaire based on the previously validated and translated 14 item questionnaire PREDIMED (Prevención com Dieta Mediterránea). Results: Most of the participants enrolled in the study were women (63\%) and between 18-35 years of age $(76.1 \%)$. The majority of the participants had moderate adherence to Mediterranean diet $(57.4 \%)$ and only $14.4 \%$ of them had high adherence. Higher adherence was reported for the use of olive oil as the primary culinary fat $(72.7 \%)$, whereas lowest adherence was achieved for wine consumption (12.4\%). Mean Mediterranean diet score did not differ significatly between women and men. Conclusions: There is a worldwide trend to adopt unhealthy eating behaviour and the results of this study indicate that eating patterns and lifestyle habits in the population have to be improved. We recommend that there is a strong need for effective strategies to promote healthy behaviour and to implement Mediterranean diet by more individuals.
\end{abstract}

Keywords: Albania, Mediterranean Diet, Adherence, Healthy Diets, Eating Patterns 


\section{Introduction}

The Mediterranean diet, represents the dietary pattern usually consumed by populations in the Mediterranean basin. Due to the various geographical regions of the Mediterranean, there are many variations of the Mediterranean diet, in which food cultures are influenced by socio-cultural, religious and economic factors (McManus et al 2001; Dernini and Berry 2016).

The Mediterranean diet has been widely reported as an ideal dietary pattern. It has been associated with health benefits and better quality of life. Also, its sustainability makes Mediterranean diet an attractive diet to promote to Western populations (McManus et al 2001; Willett 2006) .

The main components of the diet are the use of olive oil as the main type of added and cooking lipid, a high consumption of plant-based foods (vegetables, legumes, fruits and nuts), a moderate consumption of fish and dairy products (mainly as cheese and yogurt), moderate amounts of wine during meals and a low consumption of meat (Yahia N et al 2008; Baldini et al 2009; Ortiz-Moncada et al 2012; CIHEAM F 2015).

Various epidemiological studies have analysed the benefits of Mediterranean diet in comparison with other types of diets (Haveman-Nies et al 2002; Knoops et al 2006). These studies have shown that following the Mediterranean diet is associated with decreased risk of cardiovascular diseases (Hu 2002), certain types of cancer (Murtaugh et al 2007), diabetes, asthma, obesity and neurodegenerative diseases (Goulet et al 2003; Tyrovolas and Panagiotakos 2010; Buckland et al 2011; Sexton et al 2013). Moreover, people with good adherence to the Mediterranean diet have a better quality of life and greater life expectancy (Sofi et al 2008; Henríquez Sánchez et al 2011).

Therefore, it is important to evaluate the degree of adherence to Mediterranean diet through accurate measurement tools, such as dietary scores. Scores are useful instruments, based on dietary components, combining foods and nutrients to obtain valid operational variables that analyse the association between the quality of the diet and its health effects (Zazpe I et al 2008; Rumawas et al 2009; Benítez-Arciniega et al 2011). Several scores are used to measure the degree of adherence to Mediterranean diet. The first and most widely used score was created by Trichopoulou et al ( 1995). In this study we used the Validated 14-item questionnaire of the PREDIMED study, which is a brief tool assessing only a small number of foods, measured in servings/day or servings/week, that provides immediate feedback, accuracy and reliability for assessing Mediterranean diet adherence (Schröder et al 2011; Martínez-González et al 2012) .

However, in spite all these beneficial effects of the Mediterranean diet, studies indicates that there has been a rapid decline in Mediterranean diet pattern adherence in recent decades (Burlingame and Dernini 2011; Bonaccio 
et al 2016; Dernini et al 2017). Although several factors contribute to the phenomenon of nutrition transition, it seems that the change to modern lifestyles, particulary among younger, plays a major role in this shift from the traditional Mediterranean diet (Pelucchi et al 2010; Burlingame and Dernini 2011).

Albanian cousine falls in the category of the "Mediterranean diet", but data on the dietary of adults, are lacking. Therefore, the aim of the study was to investigate the level of adherence to the traditional Mediterranean diet pattern overall and to specific dietary components, among Albanian adults; thus providing evidence for intervention programs targeting this often overlooked age group.

\section{Methods}

\section{Aim}

The aim of this study was to investigate the level of adherence to the traditional Mediterranean diet pattern among Albanian adults.

\section{Hypothesis}

There is a positive relationship between educational level and adherence to the Mediterranean diet.

\section{Study's Population and Sample}

During June-July 2019, a cross-sectional survey was conducted among 209 adults (131 women, 78 men) in the cities of Vlora and Fieri, Albania. Simple Random Sampling was used during the selection of the participants. Sample size determination was calculated to achieve a confidence interval of $95 \%$, alpha level of 0.05 , and a desired level of precision of $2.5 \%$, which gave a total sample size of 206 . However, 287 potential participants were invited to take part in the study. Eligibility criteria were: (a) being currently residents in the cities of Vlora and Fieri, (b) more than 18 years old, (c), participating in the study voluntarily, (d) and actively cooperating to complete the questionnaire. Exclusion criteria were age less than 18 years of age, nonresidents and incomplete questionnaires.

From all the 287 participants initially enrolled in the study, 57 refused to participate, while 21 were excluded because of incomplete questionnaires, resulting in a final sample of 209 participants (response rate $\approx 73 \%$ ).

\section{Survey Method}

Data were collected via an online questionnaire via social networks or face to face interview from health professionals. The questionnaire was anonymous and it was divided into two sections. The first included sociodemographic data, where the participants were asked to report their gender, 
age, level of education and occupation. The second section focused on dietary patterns and adherence of the participants to the Mediterranean diet.

Mediterranean diet adherence was assessed using a validated food frequency questionnaire. The original tool was translated into Albanian. The standardized procedure of translation and back translation was followed (Cha et al., 2007). Two independent bilingual Albanian - Spanish healthcare academicians, independently translated the original instrument. Back translation by a bilingual Albanian - Spanish Phd expert was carried out. Each translated versions were evaluated by the research team, until agreement on final translation was reached.

The Albanian version was reviewed by experts for its clarity, content validity, feasibility and applicability and all necessary modifications were done. The final Albanian version was pilot tested and minor modifications were implemented according to the recommendations from the participants. The reliability of the instrument was determined through the Cronbach's Alpha and the reliability of this instrument was $(r=0.833)$.

\section{Adherence to the Mediterranean diet}

Adherence to the Mediterranean diet was assessed via an 14-item food frequency questionnaire of the PREDIMED study (Table 1) that requested participants to report the frequency of consumption of main components of the Mediterranean diet. The scores were calculated as follows: Participants would be given a score of 1 if the participants consumed more than 3 servings per week of legumes and fish; for vegetables, fruits and fruit juices criteria for 1 point was the consumption of more than 2 servings/day and more than 3 servings/day respectivelly.

For the consumption of components which are consumed less frequently in the Mediterranean diet (red meat and meat products, poultry and whole-fat dairy products, butter, sweet or carbonated beverages), a score 1 was assigned for reported consumption of the above options for less than 1 serving/day. For wine, a score of 1 was assigned for consumption of more than 7 glasses of wine per week.

Short questions were used to inquire on food habits for two of the items: Do you use olive oil as the principal source of fat for cooking? and Do you prefer to eat chicken, turkey or rabbit instead of beef, pork, hamburgers or sausages?Criteria for 1 point was answering "Yes".

The resulting total score ranged from 0 to 14 divided in three groups indicating low adherence (score $=0-5)$, moderate adherence $($ score $=6-9)$ and high adherence (score $=10-14$ ) to Mediterranean diet. 
Table 1: Validated 14-item Questionnaire of Mediterranean diet adherence.

\begin{tabular}{|l|c|}
\hline Questions & Criteria for 1 point \\
\hline 1. Do you use olive oil as main culinary fat? & Yes \\
\hline $\begin{array}{l}\text { 2. How much olive oil do you consume in a given day (including } \\
\text { oil used for frying, salads, out-of-house meals, etc.)? }\end{array}$ & $\begin{array}{c}\geq 2 \text { tbsp } \\
\text { or as a salad) }\end{array}$ \\
\hline $\begin{array}{l}\text { 3. How many vegetable servings do you consume per day? (1 } \\
\text { serving : } 200 \text { g [consider side dishes as half a serving] }\end{array}$ & $\geq 3$ \\
\hline $\begin{array}{l}\text { 4. How many fruit units (including natural fruit juices) do you } \\
\text { consume per day? }\end{array}$ & $\leq 1$ \\
\hline $\begin{array}{l}\text { 5. How many servings of red meat, hamburger, or meat products } \\
\text { (ham, sausage, etc.) do you consume per day? (1 serving: } 100-150 \\
\text { g) }\end{array}$ & \\
\hline $\begin{array}{l}\text { 6. How many servings of butter, margarine, or cream do you } \\
\text { consume per day? (1 serving: } 12 \text { g) }\end{array}$ & $<1$ \\
\hline 7. How many sweet or carbonated beverages do you drink per day? & $\geq 1$ \\
\hline 8. How much wine do you drink per week? & $\geq 3$ \\
\hline $\begin{array}{l}\text { 9. How many servings of legumes do you consume per week? (1 } \\
\text { serving : } 150 \text { g) }\end{array}$ & $\geq 3$ \\
\hline $\begin{array}{l}\text { 10. How many servings of fish or shellfish do you consume per } \\
\text { week? (1 serving 100-150 g of fish or 4-5 units or } 200 \text { g of } \\
\text { shellfish) }\end{array}$ & Yes \\
\hline $\begin{array}{l}\text { 11. How many times per week do you consume commercial sweets } \\
\text { or pastries (not homemade), such as cakes, cookies, biscuits, } \\
\text { orcustard? }\end{array}$ & $\geq 2$ \\
\hline $\begin{array}{l}\text { 12. How many servings of nuts (including peanuts) do you } \\
\text { consume per week? (1 serving } 30 \text { g) }\end{array}$ & $<3$ \\
\hline $\begin{array}{l}\text { 13. Do you preferentially consume chicken, turkey, or rabbit meat } \\
\text { instead of veal, pork, hamburger, or sausage? }\end{array}$ & $\begin{array}{l}\text { 14. How many times per week do you consume vegetables, pasta, } \\
\text { rice, or other dishes seasoned with sofrito (sauce made with } \\
\text { tomatoand onion, leek, or garlic and simmered with olive oil)? }\end{array}$ \\
\hline
\end{tabular}

\section{Statistical analyses}

Descriptive statistics (M, SD, N and \%) were used to explore demographic characteristics, and eating habits of participants. We compared the characteristics of participants according to three categories of adherence to the Mediterranean diet $(\leq 5,6-9$ and $\geq 10$ points of the 14-item questionnaire). Independent samples t-test, one-way ANOVA and chi-squared tests were used, as appropriate, to investigate any differences between males and females and to evaluate the differences among the three categories of adherence to the Mediterranean diet and their statistical significance. P-value of less than 0.05 was considered statistically significant. Data were analysed using SPSS v.19.0 (SPSS Inc., Armonk, NY) and Microsoft Office Excel 2007. 


\section{Results}

\section{Sample Size and Characteristics}

A total of 209 participants completed the survey, which included 131 women (63\%) and 78 men (37\%). The majority of participants were between 18 to 35 years of age and respondents over 65 years old were less represented than other age classes. According to their educational level $75.1 \%$ of the participants had completed university and only $3.8 \%$ of them had only primary school. Regarding occupation, a considerable percentage of the sample were students $(\approx 42 \%)$ and the remaining part had different occupational statuses such as nurses, lawyers, engineers, farmers, workers, house keepers, retired ect. (Table 2).

Table 2. Socio-Demographic Characteristics

\begin{tabular}{cccc}
\hline Gender & Female & Male & Total \\
$N$ & $131(62.7)$ & $78(37.3)$ & 209 \\
\hline Age & & & \\
$18-35$ years old & $106(80.9)$ & $53(67.9)$ & $159(76.1)$ \\
36-50 years old & $13(9.9)$ & $8(10.3)$ & $21(10.1)$ \\
$51-65$ years old & $8(6.1)$ & $9(11.5)$ & $17(8.1)$ \\
Over 65 years old & $4(3.1)$ & $8(10.3)$ & $12(5.7)$ \\
\hline Educational level & & & \\
High & $103(78.6)$ & $54(69.2)$ & $157(75.1)$ \\
Secondary & $23(17.6)$ & $21(26.9)$ & $44(21.1)$ \\
Primary & $5(3.8)$ & $3(3.9)$ & $8(3.8)$ \\
\hline Occupation & & \\
Students & $55(41.9)$ & $29(37.2)$ & $84(40.2)$ \\
Other & $76(58.1)$ & $49(62.8)$ & $125(59.8)$ \\
\hline
\end{tabular}

*Categorical variables are presented as percentages in parentheses.

\section{Adherence to the Mediterranean Diet}

As shown in Table 3, the mean Mediterranean diet score for the total study sample was 6.8 (SD 2.3), indicating moderate adherence to the Mediterranean diet. Mean values $( \pm$ SD) for the 14-item score were $6.6 \pm 2.3$ for women and $7.2 \pm 2.3$ for men, with men having a higher score compared to women, but statistically nonsignificant $(\mathrm{p}=0.056)$. The lowest score achieved by the participants from the Mediterranean diet adherence questionnaire was 2 points $(n=1)$ and the highest 12 points $(n=30)$. 
Table 3. Mean total Mediterranean diet score and differences in total Mediterranean score according to demographic characteristics .

\begin{tabular}{lllll}
\hline & $\begin{array}{l}\text { Total } \\
(\mathrm{n}=209) \\
\text { Mean }(\mathrm{Sd})\end{array}$ & $\begin{array}{l}\text { Females } \\
(\mathrm{n}=131) \\
\text { Mean }(\mathrm{Sd})\end{array}$ & $\begin{array}{l}\text { Males }(\mathrm{n}=78) \\
\text { Mean }(\mathrm{Sd})\end{array}$ & P* \\
\hline $\begin{array}{l}\text { Total Mediterranean } \\
\text { diet score }\end{array}$ & $6.8(2.3)$ & $6.62(2.3)$ & $7.21(2.3)$ & 0.056 \\
$\begin{array}{l}\text { Age group } \\
\text { 18-35 years old }\end{array}$ & $6.48(2.1)$ & $6.3(2.1)$ & $6.7(2.1)$ & 0.0013 \\
36-50 years old & $8.43(2.3)$ & $7.7(2.6)$ & $9.5(2.1)$ & \\
51-65 years old & $8.29(2.5)$ & $8.25(2.6)$ & $8.3(2.5)$ & \\
$>$ 65 years old & $7.17(1.9)$ & $7.5(2.3)$ & $7.0(1.7)$ & \\
Occupation & & & & \\
Students & $6.06(2.1)$ & $5.6(2.03)$ & $6.9(1.8)$ & \\
Others & $7.38(2.3)$ & $7.3(2.3)$ & $7.4(2.5)$ & 0.00005 \\
Educational level & & & & \\
Higher & $6.73(2.3)$ & $6.4(2.3)$ & $7.4(2.2)$ & \\
Secondary & $7.2(2.4)$ & $7.4(2.4)$ & $7.09(2.5)$ & \\
Primary & $7.1(1.6)$ & $7.2(1.9)$ & $6.0(2.1)$ & \\
\hline
\end{tabular}

*Data were presented as mean \pm SD. Differences between genders were examined using the independent samples $t$-test.

There were no differences between women and men in mean Mediterranean diet score according to their educational level (Table 3), but there were significant differences between men and women for all age groups categories, with men in the age group 18-35 years old being in the "high adherence" category compared to women $(6.7 \%$ versus $6.1 \%$, resp. $\mathrm{P}=0.0013)$.

Students exhibited a lower adherence to the Mediterranean diet compared to other categories of the occupational status (6.06 vs 7.38, $\mathrm{p}<0.00005$ ). (Table 3). Overall, $57.8 \%$ of the students showed moderate adherence to the diet, $38.6 \%$ of them low adherence and only $3.6 \%$ high adherence (Table 4).

Table 4. Characteristics of participants by adherence to the Mediterranean diet

\begin{tabular}{|c|c|c|c|c|c|c|c|c|}
\hline \multirow[b]{2}{*}{ Adherence } & \multicolumn{3}{|c|}{ Woman } & \multicolumn{5}{|c|}{ Men } \\
\hline & $0-5$ & $6-9$ & $10-14$ & $\mathrm{P}^{*}$ & $0-5$ & $6-9$ & $10-14$ & \multirow{2}{*}{$\mathrm{P}^{*}$} \\
\hline$N$ & 41 & 74 & 16 & & 18 & 46 & 14 & \\
\hline \multicolumn{9}{|c|}{ Educational level } \\
\hline High & $34(26)$ & $58(44.2)$ & $11(8.3)$ & 0.14 & $11(14.1)$ & $33(42.3) 1$ & $10(12.8)$ & 0.56 \\
\hline Secondary & $6(4.6)$ & $13(9.9)$ & $4(3.1)$ & & $6(7.7)$ & $1(14.1)$ & $4(5.1)$ & \\
\hline $\begin{array}{c}\text { Primary } \\
\text { Age }\end{array}$ & $1(0.8)$ & $3(2.3)$ & $1(0.8)$ & & $1(1.3)$ & $2(2.6)$ & $0(0)$ & \\
\hline $18-35$ years old & $37(28)$ & $61(46.7)$ & $8(6.1)$ & 0.02 & $16(20.5)$ & $30(38.5)$ & $7(8.9)$ & $\begin{array}{c}0.00 \\
5\end{array}$ \\
\hline $36-50$ yearsold & $2(1.5)$ & $8(6.1)$ & $3(2.3)$ & & $0(0)$ & $5(6.4)$ & $3(3.8)$ & \\
\hline $51-65$ years old & $1(0.8)$ & $3(2.3)$ & $4(3.1)$ & & $1(1.3)$ & $5(6.4)$ & $3(3.8)$ & \\
\hline$>65$ years old & $1(0.8)$ & $2(1.5)$ & $1(0.8)$ & & $1(1.3)$ & $6(7.7)$ & $1(1.3)$ & \\
\hline
\end{tabular}


$0(0)$

*One-way ANOVA tests (continuous variables) or chi squared tests (categorical variables).

\section{Consumption of main components of the Mediterranean diet}

When looking at categories of adherence in all groups, about half (57.4\%) were in the "intermediate adherence" to the Mediterranean diet category (score 6-9), 28.2\% were in the "low adherence" category (total score of $\leq 5$ ), and $14.4 \%$ were in the "high adherence" category (total score 10-14) (Table 5).

Table 5. Adherence of the participants for each of the components of the Mediterranean diet

\begin{tabular}{|c|c|c|c|c|}
\hline & $\begin{array}{l}\text { Total } \\
(\mathrm{n}=209)\end{array}$ & $\begin{array}{l}\text { Females } \\
(\mathrm{n}=131)\end{array}$ & $\begin{array}{l}\text { Males } \\
(\mathrm{n}=78)\end{array}$ & $\mathrm{P}^{*}$ \\
\hline Adherence to the Mediterranean diet & & & & 0.056 \\
\hline Low $($ score $=0-5$ ) & $59(28.2)$ & $41(31.3)$ & $18(23.1)$ & \\
\hline \multicolumn{5}{|l|}{ Moderate $($ score $=6-9)$} \\
\hline High $($ score $=10-14)$ & $120(57.4)$ & $74(56.5)$ & $46(59)$ & \\
\hline & $30(14.4)$ & $16(12.2)$ & $14(17.9)$ & \\
\hline Olive oil as main culinary fat & & & & 0.29 \\
\hline Low $($ score $=0)$ & $57(27.3)$ & $39(29.8)$ & $18(23.1)$ & \\
\hline $\operatorname{High}(\operatorname{score}=1)$ & $152(72.7)$ & $92(70.2)$ & $60(76.9)$ & \\
\hline Olive oil $\geq 4$ tbsp/day & & & & 0.62 \\
\hline Low $($ score $=0)$ & $108(51.7)$ & $66(50.4)$ & $42(53.8)$ & \\
\hline $\operatorname{High}(\operatorname{score}=1)$ & $101(48.3)$ & $65(49.6)$ & $36(46.2)$ & \\
\hline Vegetables $\geq 2$ servings $/ \mathrm{d}$ & & & & 0.08 \\
\hline Low $($ score $=0)$ & $99(47.4)$ & $68(51.9)$ & $31(39.7)$ & \\
\hline $\operatorname{High}($ score $=1)$ & $110(52.6)$ & $63(48.1)$ & $47(60.3)$ & \\
\hline Fruits $\geq 3$ servings $/ \mathrm{d}$ & & & & 0.4 \\
\hline Low $($ score $=0)$ & 107(51.2) & $70(53.4)$ & $37(47.4)$ & \\
\hline $\operatorname{High}(\operatorname{score}=1)$ & $102(48.8)$ & $61(46.6)$ & $41(52.6)$ & \\
\hline Red meat $<1 /$ d & & & & 0.04 \\
\hline Low $($ score $=0)$ & $63(30.1)$ & $46(35.1)$ & $17(21.8)$ & \\
\hline $\operatorname{High}($ score $=1)$ & $146(69.9)$ & $85(64.9)$ & $61(78.2)$ & \\
\hline Butter $<1 / \mathrm{d}$ & & & & 0.08 \\
\hline Low $($ score $=0)$ & $27(12.9)$ & $21(16.0)$ & $6(7.7)$ & \\
\hline $\operatorname{High}(\operatorname{score}=1)$ & $182(87.1)$ & $110(84.0)$ & $72(92.3)$ & \\
\hline Sweet or carbonated beverages $<1 / d$ & & & & 0.9 \\
\hline Low $($ score $=0)$ & $76(36.4)$ & $48(36.6)$ & $28(35.9)$ & \\
\hline $\operatorname{High}($ score $=1)$ & $133(63.6)$ & $83(63.4)$ & $50(64.1)$ & \\
\hline Wine adherence & & & & 0.006 \\
\hline Low $($ score $=0)$ & $183(87.6)$ & $121(92.4)$ & $62(79.5)$ & \\
\hline $\operatorname{High}($ score $=1)$ & $26(12.4)$ & $10(7.6)$ & $16(20.5)$ & \\
\hline Legumes $\geq 3 / \mathrm{wk}$ & & & & 0.056 \\
\hline Low $($ score $=0)$ & $135(64.6)$ & $91(69.5)$ & $44(56.4)$ & \\
\hline $\operatorname{High}($ score $=1)$ & $74(35.4)$ & $40(30.5)$ & $36(43.6)$ & \\
\hline Fish $\geq 3 /$ wk & & & & 0.32 \\
\hline
\end{tabular}




\begin{tabular}{lllll} 
Low $($ score=0) & $163(78.0)$ & $105(80.2)$ & $58(74.4)$ & \\
High(score=1) & $46(22.0)$ & $26(19.8)$ & $20(25.6)$ & \\
$\begin{array}{l}\text { Sweets } \leq 2 / \mathrm{wk} \\
\text { Low }(\text { score=0) }\end{array}$ & $141(67.5)$ & $91(69.5)$ & $50(64.1)$ & 0.42 \\
High(score=1) & $68(32.5)$ & $40(30.5)$ & $28(35.9)$ & \\
$\begin{array}{l}\text { Nuts adherence } \\
\text { Low (score=0) }\end{array}$ & $179(85.6)$ & $113(86.3)$ & $66(84.6)$ & \\
$\begin{array}{l}\text { High(score=1) } \\
\text { Poultry instead of red meat? }\end{array}$ & $30(14.4)$ & $18(13.7)$ & $12(15.4)$ & \\
$\begin{array}{l}\text { Low (score=0) } \\
\text { High(score=1) }\end{array}$ & $39(18.7)$ & $32(24.4)$ & $7(9.0)$ & 0.005 \\
$\begin{array}{l}\text { Vegetables, pasta, rice/week } \\
\text { Low (score=0) }\end{array}$ & $170(81.3)$ & $99(75.6)$ & $71(91.0)$ & \\
High(score=1) & & & & 0.61 \\
\hline
\end{tabular}

*Differences between genders were examined using the Chi-square test.

\section{Conclusion}

In this study participants reported moderate levels of adherence to the Mediterranean diet, with higher adherence in participants between 18-35 years old. Students had a poor adherence to Mediterranean diet compared to the other participants.

To our knowledge, there are a few studies in Albania on eating patterns and adherence to the Mediterranean diet in adults. Our results support the proposed_shift from traditional healthy diets to more unhealthy eating patterns in Mediterranean countries. Based on this findings, future interventions and public health strategies should be implemented, focusing not only in promoting consumption of several components of the Mediterranean diet, but also on cultural and social dimensions that characterize its heritage.

Further research on the main determinants of individual adherence to Mediterranean diet would make a significant contribution to extend current evidence on this issue.

\section{References:}

1. Baldini M, Pasqui F, Bordoni A, Maranesi M. Is the Mediterranean lifestyle still a reality? Evaluation of food consumption and energy expenditure in Italian and Spanish university students. Public health nutrition. 2009 Feb;12(2):148-55.

2. Benítez-Arciniega AA, Mendez MA, Baena-Díez JM, Martori MA, Soler C, Marrugat J, Covas MI, Sanz H, Llopis A, Schröder H. Concurrent and construct validity of Mediterranean diet scores as assessed by an FFQ. Public health nutrition. 2011 Nov;14(11):201521.

3. Buckland G, Agudo A, Travier N, Huerta JM, Cirera L, Tormo MJ, Navarro C, Chirlaque MD, Moreno-Iribas C, Ardanaz E, Barricarte A. Adherence to the Mediterranean diet reduces mortality in the Spanish 
cohort of the European Prospective Investigation into Cancer and Nutrition (EPIC-Spain). British journal of nutrition. 2011 Nov;106(10):1581-91.

4. Burlingame B, Dernini S. Sustainable diets: the Mediterranean diet as an example. Public health nutrition. 2011 Dec;14(12A):2285-7.

5. Cabrera SG, Fernández NH, Hernández CR, Nissensohn M, RománViñas B, Serra-Majem L. KIDMED test; prevalence of low adherence to the Mediterranean Diet in children and young; a systematic review. Nutricion hospitalaria. 2015;32(6):2390-9.

6. Cha, E., Kim, K.H., \& Erlen, J.A. (2007). Translation of scales in cross-cultural research: issues and techniques. Journal of advanced nursing, 58 4, 386-95.

7. CIHEAM F. Mediterranean food consumption patterns: diet, environment, society, economy and health. A White Paper of Priority. 2015;5.

8. Dernini S, Berry EM, Serra-Majem L, La Vecchia C, Capone R, Medina FX, Aranceta-Bartrina J, Belahsen R, Burlingame B, Calabrese G, Corella D. Med Diet 4.0: the Mediterranean diet with four sustainable benefits. Public health nutrition. 2017 May;20(7):1322-30.

9. Dernini S, Berry EM. Historical and behavioral perspectives of the Mediterranean diet. InMediterranean Diet 2016 (pp. 29-41). Humana Press, Cham.

10. Ebbeling CB, Pawlak DB, Ludwig DS. Childhood obesity: publichealth crisis, common sense cure. The lancet. 2002 Aug 10;360(9331):473-82.

11. Fletcher DJ, Rogers DA. Diet and coronary heart disease: helping patients reduce serum cholesterol level. Postgraduate medicine. 1985 Apr 1;77(5):319-28.

12. Goulet J, Lamarche B, Nadeau G, Lemieux S. Effect of a nutritional intervention promoting the Mediterranean food pattern on plasma lipids, lipoproteins and body weight in healthy French-Canadian women. Atherosclerosis. 2003 Sep 1;170(1):115-24

13. Grosso G., Marventano S., Giorgianni G., Raciti T., Galvano F., Mistretta A. Mediterranean diet adherence rates in sicily, southern Italy. Public Health Nutr. 2014;17:2001-2009. doi: 10.1017/S1368980013002188.

14. Haveman-Nies A, de Groot LC, Burema J, Cruz JA, Osler M, van Staveren WA. Dietary quality and lifestyle factors in relation to 10year mortality in older Europeans: the SENECA study. American journal of epidemiology. 2002 Nov 15;156(10):962-8.

15. Hadjimbei E, Botsaris G, Gekas V, Panayiotou AG. Adherence to the Mediterranean diet and lifestyle characteristics of University students 
in Cyprus: A cross-sectional survey. Journal of nutrition and metabolism. 2016;2016.

16. Henríquez Sánchez, P., Ruano, C., de Irala, J. et al. Adherence to the Mediterranean diet and quality of life in the SUN Project. Eur J Clin Nutr 66, 360-368 (2012). https://doi.org/10.1038/ejcn.2011.146

17. Hoşcan, Y., Yiğit, F., \& Müderrisoğlu, H. (2015). Adherence to Mediterranean diet and its relation with cardiovascular diseases in Turkish population. International journal of clinical and experimental medicine, 8(2), 2860-2866.

18. Hu FB. Dietary pattern analysis: a new direction in nutritional epidemiology. Current opinion in lipidology. 2002 Feb 1;13(1):3-9.

19. Hubert HB, Feinleib M, McNamara PM, Castelli WP. Obesity as an independent risk factor for cardiovascular disease: a 26-year follow-up of participants in the Framingham Heart Study. Circulation. 1983 May;67(5):968-77.

20. Katsarou A, Tyrovolas S, Psaltopoulou T et al. (2010) Socioeconomic status, place of residence and dietary habits among the elderly: the Mediterranean islands study. Public Health Nutr 13, 1614-1621.

21. Knoops KT, Fidanza F, Alberti-Fidanza A, Kromhout D, Van Staveren WA. Comparison of three different dietary scores in relation to 10-year mortality in elderly European subjects: the HALE project. European journal of clinical nutrition. 2006 Jun;60(6):746-55.

22. Kontogianni MD, Vidra N, Farmaki AE, Koinaki S, Belogianni K, Sofrona S, Magkanari F, Yannakoulia M. Adherence rates to the Mediterranean diet are low in a representative sample of Greek children and adolescents. The Journal of nutrition. 2008 Oct 1;138(10):1951-6.

23. Leblanc V, Bégin C, Corneau L, Dodin S, Lemieux S. Gender differences in dietary intakes: what is the contribution of motivational variables?. Journal of Human Nutrition and Dietetics. 2015 Feb;28(1):37-46.

24. Leone, A., Battezzati, A., De Amicis, R., De Carlo, G., \& Bertoli, S. (2017). Trends of Adherence to the Mediterranean Dietary Pattern in Northern Italy from 2010 to 2016. Nutrients, 9(7), 734. https://doi.org/10.3390/nu9070734

25. Martínez-González MÁ, Corella D, Salas-Salvadó J, Ros E, Covas MI, Fiol M, Wärnberg J, Arós F, Ruíz-Gutiérrez V, Lamuela-Raventós RM, Lapetra J. Cohort profile: design and methods of the PREDIMED study. International journal of epidemiology. 2012 Apr 1;41(2):377-85

26. McManus K, Antinoro L, Sacks F. A randomized controlled trial of a moderate-fat, low-energy diet compared with a low fat, low-energy 
diet for weight loss in overweight adults. International journal of obesity. 2001 Oct;25(10):1503-11.

27. Moreno LA, Sarria A \& Popkin BM (2002) The nutrition transition in Spain: a European Mediterranean country. Eur J Clin Nutr 56, 9921003.

28. Murtaugh MA, Herrick JS, Sweeney C, Baumgartner KB, Guiliano AR, Byers T, Slattery ML. Diet composition and risk of overweight and obesity in women living in the southwestern United States. Journal of the American Dietetic Association. 2007 Aug 1;107(8):1311-21

29. Ortiz-Moncada R, Norte AN, Zaragoza AM, Fernández JS, Davó MB. Do the Spanish university students follow Mediterranean dietary patterns?. Nutricion hospitalaria. 2012;27(6):1952-9.

30. Papadaki A, Wood L, Sebire SJ, Jago R. Adherence to the Mediterranean diet among employees in South West England: Formative research to inform a web-based, work-place nutrition intervention. Preventive medicine reports. 2015 Jan 1;2:223-8.

31. Pelucchi C, Galeone C, Negri E et al. (2010) Trends in adherence to the Mediterranean diet in an Italian population between 1991 and 2006. Eur J Clin Nutr 64, 1052-1056

32. Rumawas ME, Dwyer JT, Mckeown NM, Meigs JB, Rogers G, Jacques PF. The development of the Mediterranean-style dietary pattern score and its application to the American diet in the Framingham Offspring Cohort. The Journal of nutrition. 2009 Jun $1 ; 139(6): 1150-6$.

33. San IM, Megias A, de Angulo García B, Bodega P, Rodriguez P, Grande G, Mico V, Romero E, Garcia N, Fajardo D, Garicano E. The influence of healthy lifestyle habits on weight status in school aged children and adolescents. Nutricion hospitalaria. 2015 May;31(5):1996-2005

34. Sexton P, Black P, Metcalf P, Wall CR, Ley S, Wu L, Sommerville F, Brodie S, Kolbe J. Influence of Mediterranean diet on asthma symptoms, lung function, and systemic inflammation: a randomized controlled trial. Journal of asthma. 2013 Feb 1;50(1):75-81.

35. Schröder H, Fitó M, Estruch R, Martínez-González MA, Corella D, Salas-Salvadó J, Lamuela-Raventós R, Ros E, Salaverría I, Fiol M, Lapetra J. A short screener is valid for assessing Mediterranean diet adherence among older Spanish men and women. The Journal of nutrition. 2011 Jun 1;141(6):1140-5.

36. Sogari G, Velez-Argumedo C, Gómez MI, Mora C. College students and eating habits: A study using an ecological model for healthy behavior. Nutrients. 2018 Dec;10(12):1823. 
37. Sofi F, Cesari F, Abbate R, Gensini GF, Casini A. Adherence to Mediterranean diet and health status: meta-analysis. Bmj. 2008 Sep 11;337:a1344.

38. Trichopoulou A, Kouris-Blazos A, Wahlqvist ML, Gnardellis C, Lagiou P, Polychronopoulos E, Vassilakou T, Lipworth L, Trichopoulos D. Diet and overall survival in elderly people. Bmj. 1995 Dec 2;311(7018):1457-60.

39. Tyrovolas S, Panagiotakos DB. The role of Mediterranean type of diet on the development of cancer and cardiovascular disease, in the elderly: a systematic review. Maturitas. 2010 Feb 1;65(2):122-30.

40. Yahia N, Achkar A, Abdallah A, Rizk S. Eating habits and obesity among Lebanese university students. Nutrition journal. 2008 Dec;7(1):32.

41. Zazpe I, Sanchez-Tainta A, Estruch R, Lamuela-Raventos RM, Schröder H, Salas-Salvado J, Corella D, Fiol M, Gomez-Gracia E, Aros F, Ros E. A large randomized individual and group intervention conducted by registered dietitians increased adherence to Mediterranean-type diets: the PREDIMED study. Journal of the American Dietetic Association. 2008 Jul 1;108(7):1134-44.

42. Willett WC. The Mediterranean diet: science and practice. Public health nutrition. $2006 \mathrm{Feb}$;9(1a):105-10. 